\title{
DESIGNING BEACHSIDE RESORT AT PANTAI INDAH KALANGAN, CENTRAL TAPANULI WITH VERNACULAR ARCHITECTURE APPROACHMENT
}

\author{
Imam Faisal Pane', Maria Isabella Zebua ${ }^{1}$ \\ 1. Architecture Department, Faculty of Engineering, Universitas Sumatera Utara, Medan, \\ Indonesia \\ Jl. Perpustakaan St. J07 Building, Medan, 20155, Indonesia \\ *Email: wasilah@uin-alauddin.ac.id
}

\begin{abstract}
Central Tapanuli is known for many stunning tourist locations, mainly its stretch of beach so that it becomes a great potential as an area of tourism with adequate accommodation as well as resorts. Some problems in the design resort that attract the attention and interest of tourist to come, how to design space programs according to human needs in it, and how to design buildings that are responsive to local climate, cultural and social conditions. From these problems, it is intended to create resorts with a variety of recreational facilities, design inner spaces and outdoor spaces according to resorts needs and local wisdom, and can introduce local culture to foreign tourists through resort design. Therefore, the research conducted by collecting existing location information, literature studies, comparative studies, and field surveys. After doing each step above, the result obtained, namely the design of the Beachside Resort using vernacular architecture, which is applied to each form of resort building, ranging from hotel, restaurant, cottages, spa and sauna, and other supporting facilities, using the types of the Central Tapanuli household, combined with the application of "Dalihan Natolu". By obtaining these result, it is expected to become tourism locations and become a positive response in bringing back the traditional architecture of Central Tapanuli.
\end{abstract}

Keywords: beach, Central Tapanuli, resort, vernacular.

\section{INTRODUCTION}

Indonesia has a natural potential that is very stunning with various attractions in it. Tourism is the main role in economic, social, or cultural aspects, which will bring in foreign exchange for the country, new jobs, stabilize the local economy, bringing new skills, as well as an introduction to the culture [1]. Stunning tourist locations in Indonesia are very numerous, tourist attraction is something that can encourage tourists to visit and vacation in the tourist destination [2].

The resort is one of the appropriate accommodation that can accommodate any activity that equipped with tourism attractions and other services with the aim to meet the needs of travelers [1], Therefore, in designing a resort needs to pay attention to the proper location so that every design implemented by the supposed function. According to Lawson
(1995), a principle that must meet in the design of the resort consists of individual needs and requirements in tourism activities, a unique experience for tourists, and create an attractive tourist image [3]. One important factor in realizing forms in architecture is a function because basically, architecture is a place to fulfill architectural needs [4]. Pantai Indah Kalangan is one of the many locations in Central Tapanuli, that can be developed for tourism potential. Central Tapanuli also known as ethnic shores, but the existence of traditional architecture in the form of house stage increasingly eroded due to the times, so that the theme can apply as an embodiment vernacular coastal architecture of Central Tapanuli.

\section{LITERATURE REVIEW}

The resort is a temporary residence for someone with the aim among others, to get the 
freshness of body and soul as well as the desire to know something new. It can also attribute to the interest associated with sports activities, health, conventions, religious, and other business purposes [3]. The resort is a tourist area or sites to be equipped with various facilities and other travel services business with the aim to meet the needs of travelers who managed integrated under one management [1]. The location must also have potential and beautiful scenery that it can provide relaxation and recovery from solid routines [5].

The types of resort based on the location of the orientation of the view that is a resort located in the mountains (Mountain Resort), resort on the seaside (Beachside Resort), resort on the shore of the lake (Lake Resort), resort on the top of the mountain (Hill Resort), resort area of protected forest (forest Resort) [3]. Beachside Resort is a resort on the beach or by the sea, with its main focus is the ocean itself as an object of recreation [6]. Vernacular Architecture theme applied to the building in which the observer is trying to bring back the coastal architecture, almost lost in these locations. There are some typical architectures of the Coastal ethnicity, namely stilts with wooden carvings are striking.

Vernacular is an ecological value that is responsive to its environment and always refers to the potential of abilities and skills, practical knowledge and traditional techniques which are usually carried out alone or assisted by the local community [7]. Although vernacular architecture does not change due to its traditional nature and always used as a rule, condition, and guidelines that are passed down through generations. Nevertheless, if it happens continuously, it can also experience extinction [8]. Even so, vernacular architecture often associated with famous architecture [9]. Therefore, in determining the stage of research, it is necessary to understand the essence of a vernacular architecture according to various sources, then identify aspects that exist in the study [10].

\section{METHODOLOGY}

The methodology used in the design of buildings in the form of survey resort directly to the field, comparative studies and literature studies where the data relating to the design of the seaside resort and related themes were collected and assessed. Besides the interview method on host communities design is also done, to get more information. The location is determined based on several criteria from the selection of resort design locations. Located at Jalan Padangsidimpuan Central Tapanuli, precisely in Pandan town beach with potential, and access can be reached easily either from the airports Dr. Ferdinand Lumban Tobing and from Sibolga (Figure 1).

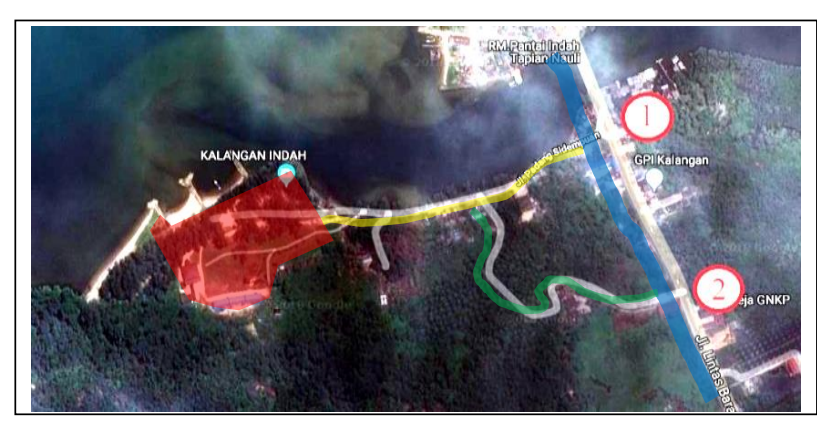

Figure 1. Location of Design (Source: Google.com)

\section{RESULTS AND DISCUSSION}

The design location is on Padangsidimpuan road, Pandan, Central Tapanuli with an area of $\pm 30162.75 \mathrm{~m} 2$ site. The site bordered by the beach in the north, circulation, and houses in the east, and the hills in the south and west. Site location can be reached either \pm 30 minutes from the airport Dr. Ferdinand Lumban Tobing and Sibolga. The type of vehicle that passes through the site includes a car, public transport, rickshaws, buses, and motorcycles.

\section{The Composition of The Mass}

The concepts applied to buildings is vernacular architecture. The approach is taken also adapted to the natural conditions, building materials, as well as the behavior patterns of the surrounding community. As for the design location in Central Tapanuli, so that the shape of the building is taken based on ethnic house building that is on site. According to Syafrial Marbun who is an observer of the coastal culture of Central Tapanuli - Sibolga, Central Tapanuli - Sibolga doesn't have a traditional house, but there is a coastal community with the typical house has carvings of bees clinging, stilts. (Figure 2). It also justified by the Foundation plinth in Sibolga Pasisi Tapteng (LPST). Therefore, for the design of resorts are based on a coastal house which is also the 
embodiment of vernacular. Also, Central Tapanuli people also still apply "Dalihan Natolu" (Figure 3). This resort designed with three parts, the main building as Dongan Tubu, and both wings as Hula and Boru (Figure 4).

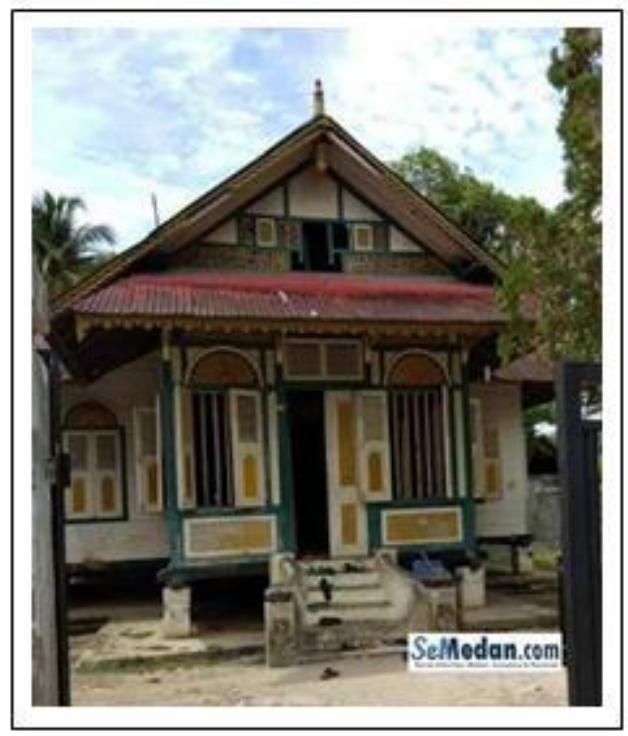

Figure 2. House of "Raja Sorkam" (Source: Google.com)

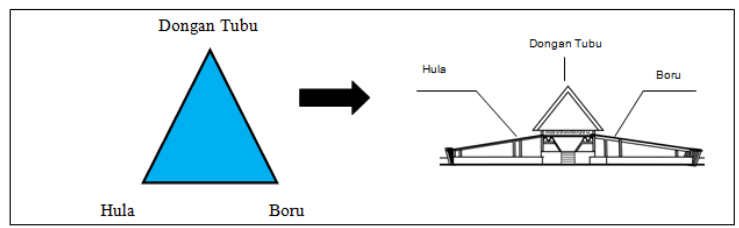

Figure 3. Application Dalihan Natolu on Buildings

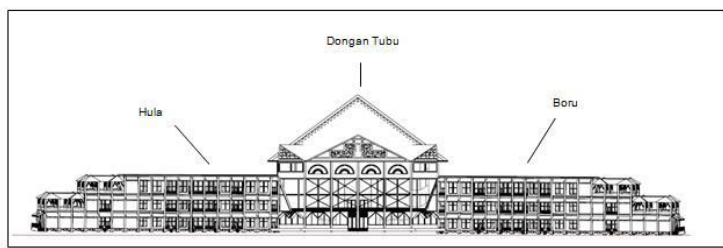

Figure 4. The concept of Main Building

In the main building which is a hotel, the concept of the Central Tapanuli traditional house is made clear with the details of each ornament. The roof made in such a way as the "lisplang" characterizes the typical Central Tapanuli house, the ventilation the resembles the Sari Bulan vent, and the stilt house with a height of $\pm 80 \mathrm{~cm}$ (Figure 5). Mass of the building on both wings sloped to the slope of \pm $6.5^{\circ}$ so that the air coming from the hill can quickly drain. In addition to the two wings of the building was made up and down with the function of relaxing area, with the aim that maximum air can get into the room (Figure 6).

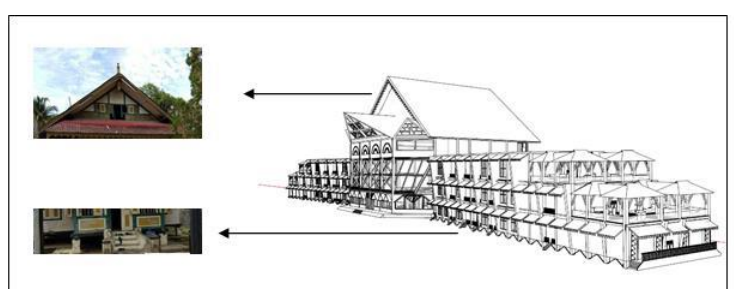

Figure 5. The concept of Main Building Façade

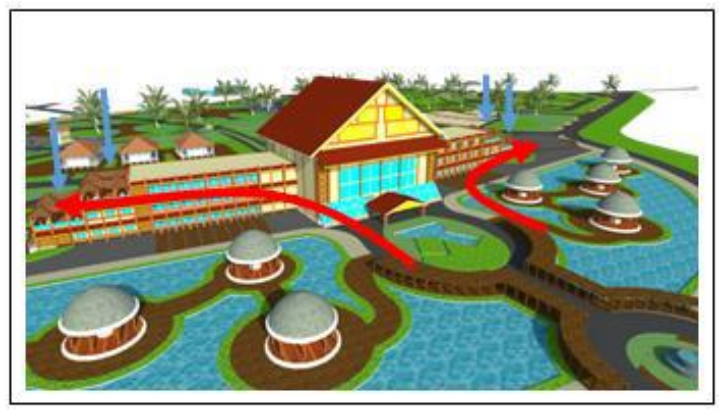

Figure 6. Building Future Concepts

\section{The design of the tread}

Entrance from the street Padangsidimpuan then drops off towards the main building or the parking area directly. Visitors who want to go to the resort are escorted by car to resort facilities. Restaurant, spa, swimming pool, and a souvenir craft area applied outside the main building with the aim that visitors staying in the hotel building or cottage can feel the atmosphere of the resort area when heading to the facilities provided. Also, the service area and a mess of employees placed behind the main building (Figure 7).

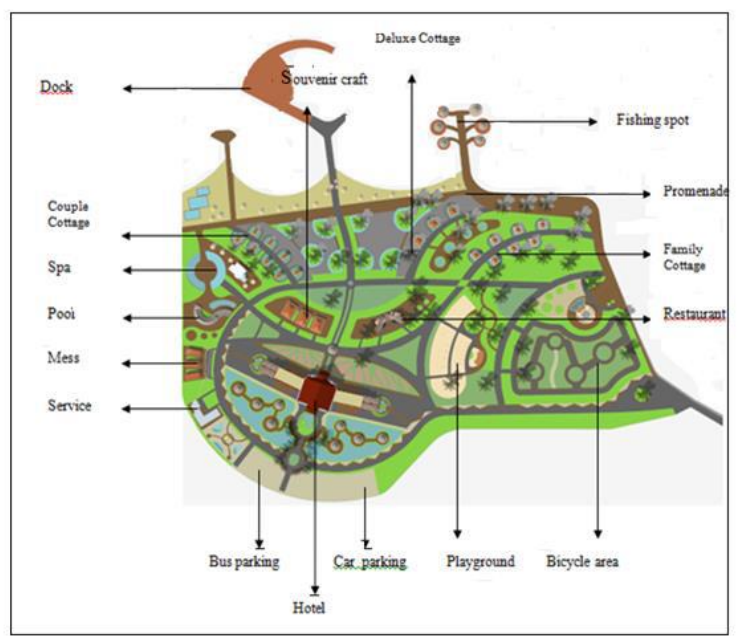

Figure 7. Tread Design Concept

\section{The facade}

The facade of the main building was made following the traditional home of coastal Central Tapanuli stilts and decorated with ornamental 
carving. Also, the bright colors also applied to the ornament carving (Figure 8).

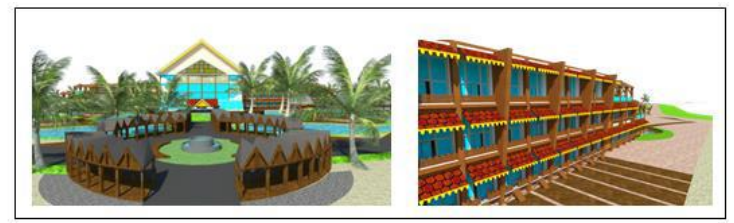

Figure 8. The concept façade

\section{The Shape Building cottages and Facilities}

Similar to the main building, Couple Cottage, Family Cottage, and Deluxe Cottage also apply the concept of a traditional house Central Tapanuli stilts with carvings Central Tapanuli (Figure 9). No different from the main concept, other resort facilities is also an application of Central Tapanuli Traditional house. In the restaurant building, Dalihan Natolu shown on the three roofs centered in the center of the building with ornaments that match the original. However, the form of the stage house was not applied (Figure 10).

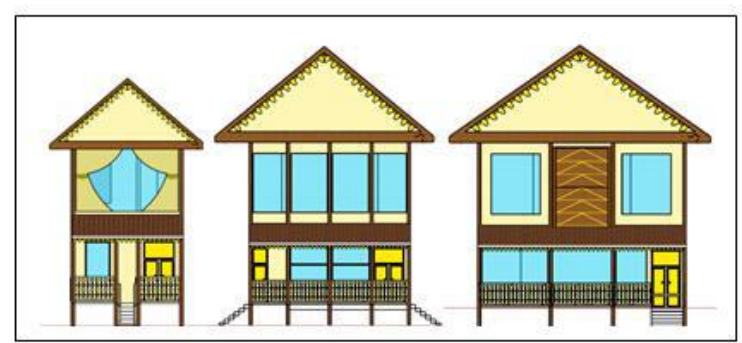

Figure 9. The concept of building Massa Cottage

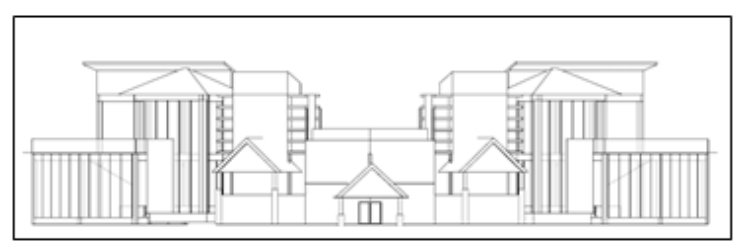

Figure 10. Mass Building Concept Restaurants

The concept of the craft building applies the house on stilts and still uses ornamented gable roofs. However, the roof as slightly lowered next to it, as the path of light enters the room (Figure 11). Spa and sauna buildings use the same concept, but a little modern impression given to the window section with ornate triangle models (Figure 12).

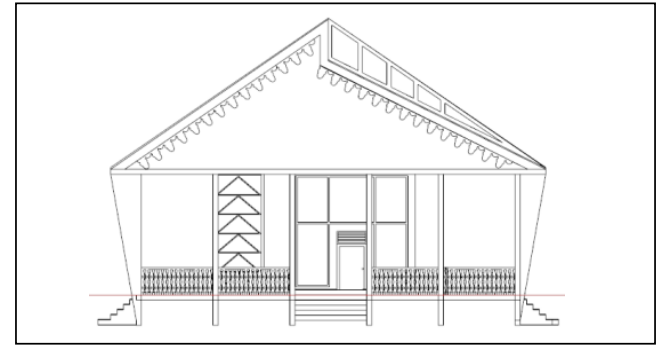

Figure 11. Mass Concept Building Craft Room

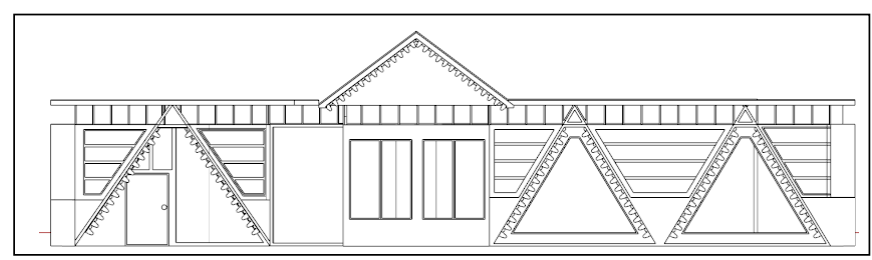

Figure 12. Mass Building Concept Spa and Sauna

\section{In the Space Organization}

The concept of space in the building this resort primarily on each room made simple with materials such as exposed brick in most area. Each room also has a balcony to enjoy the outdoor atmosphere of each room has a direct resort. In each wing of the building there is also a relaxing outdoor area, so visitors are in a superior room can also enjoy the beach, and vice versa on the visitor in a deluxe room or suite (Figure 13).

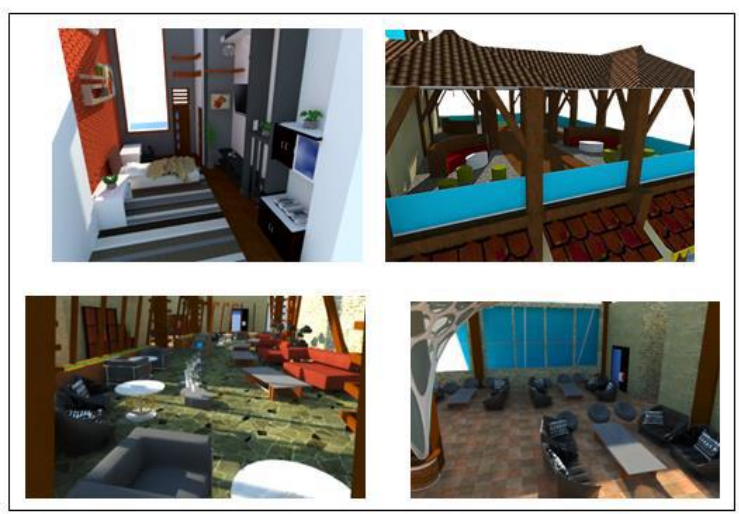

Figure 13. Atmosphere Interior Main Building

\section{Zoning}

On the first floor of the hotel, there a lobby, lounge, retail, café as a public area, and rooms as private areas. Then, fitness room, retails, and bar as semi-private areas on the next floor. While on the third there are café, retail, and bakeries as semi-private areas, and rooms as private areas. The last, the fourth floor has a hall, meeting room, and rest area as semi-private area (Figure 14). The concept of spatial design of the main building resort is as follows : 


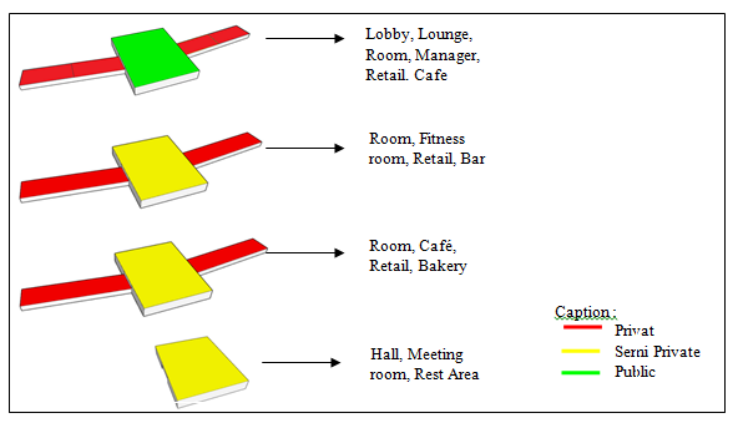

Figure 14. Zoning and spatial structure

\section{CONCLUSION}

The design of Beachside Resort Pantai Indah Kalangan the aims in building the economy of Central Tapanuli society. Also, by applying a theme Vernacular, would be able to bring back the traditional architecture of coastal Central Tapanuli has been lost. The location is also a tourist spot for both residents and visitors which will provide jobs for the containers around as the resort staff. The concept of the design theme taken from traditional stilt houses Central Tapanuli coastal communities with various ornamental carving, "lisplang" as well as the wind hole. It aims to reintroduce to the people of Central Tapanuli regarding coastal architecture that is almost gone.

\section{Acknowledgment}

This research is a scientific work related to efforts to maintain local wisdom in Central Tapanuli. This design can be a guide by the Central Tapanuli's government for the buildings in Central Tapanuli so that Central Tapanuli doesn't lose identity.

\section{Daftar Pustaka}

Darsiharjo \& R. Nurazizah (2014) Konsep Resort Yang Berkelanjutan (Kasus Resort Di Indonesia). Jurnal Manajemen Resort \& Leisure, 11(2).

H. Tjahjono (2010) Analisis Potensi dan Masalah Pariwisata di Kelurahan Kandari. Forum Ilmu Sosial, 37(2).

S. Ega (2015) Resort Di Pantai Kura-Kura Bengkayang. Jurnal Arsitektur Universitas Tanjungpura, 3(2)I.
F. Zubaidi (2009) Arsitektur Kaili Sebagai Proses dan Produk Vernakular, Jurnal Ruang, 1(1).

R. Mahdi (2012) Studi Perancangan Fasilitas Hotel Resort Untuk Mengangkat Potensi Wisata Sejarah di Pulau Bidadari Kepulauan Seribu, Jurnal Tingkat Sarjana Bidang Senirupa dan Desain, (1).

A. Ramadhan (2013) Kawasan Hotel Resort Dan Homestay Di Pulau Lemukutan Kabupaten Bengkayang, Jurnal Arsitektur Langkau Betang, 1(1).

Wiranton (1999) Arsitektur Vernakulat Indonesia : Perannya Dalam Pengembangan Jati Diri, Dimesi Teknik Arsitektur, 27(2).

J. Rengkung (2011) Arsitektur Vernakular Rumah Tinggal Masyarakat Etnik Minahasa, Media Matrasain, 8(3).

P. Oliver (2006) Built to Meet Needs Cultural Issues in Vernacular Architecture. Oxford: Elsevier Ltd.

I. Mentayani (2012) Menggali Makna Arsitektur Vernakular: Ranah, Unsur, dan Aspek-Aspek Vernakularitas. Lanting Journal of Architecture, l(2). 